\title{
DESKRIPSI PROSES KEPUTUSAN PEMBELIAN SAYURAN ORGANIK YANG DILAKUKAN OLEH KONSUMEN WARUNG SEHAT 1000 KEBUN BANDUNG
}

\section{DESCRIPTION OF THE PURCHASE DECISION PROCESS OF ORGANIC VEGETABLES OF "WARUNG SEHAT 1000 KEBUN" CONSUMERS, BANDUNG}

\author{
Tasya Maulida Hermansyah**1, Kuswarini Kusno ${ }^{2}$ \\ ${ }^{1}$ Program Studi Agribisnis Fakultas Pertanian Universitas Padjadjaran \\ ${ }^{2}$ Departemen Sosial Ekonomi Pertanian Fakultas Pertanian Universitas Padjadjaran \\ Jl. Raya Bandung-Sumedang Km. 21 \\ *E-mail: tasya18006@mail.unpad.ac.id \\ (Diterima 30-12-2021; Disetujui 22-01-2022)
}

\begin{abstract}
ABSTRAK
Tren konsumsi sayuran organik di perkotaan tengah mengalami peningkatan. Warung Sehat 1000 Kebun Bandung merupakan salah satu pemasar sayuran organik di Kota Bandung. Banyaknya kompetitor dan menjamin ketersediaan sayuran organik sesuai kebutuhan konsumen menjadi persoalan yang sedang dihadapi. Penelitian ini bertujuan untuk mendeskripsikan karakteristik konsumen, proses keputusan pembelian, dan menganalisis faktor-faktor yang mempengaruhi keputusan pembelian konsumen. Penelitian ini menerapkan desain kuantitatif dengan teknik survei terhadap 42 responden. Pengambilan sampel dilakukan secara convenience. Data dianalisis dengan distribusi frekuensi untuk mengetahui deskripsi karakteristik konsumen, proses keputusan pembelian, dan faktor-faktor yang mempengaruhi keputusan pembelian konsumen. Berdasarkan hasil penelitian, konsumen sayuran organik di Warung Sehat 1000 Kebun Bandung sebagian besar adalah perempuan berusia 36-45 tahun dan 56-65 tahun, sudah menikah, merupakan ibu rumah tangga, dan berpendapatan $>$ Rp6.000.000. Konsumsi sayuran organik dilakukan secara tidak menentu. Kesehatan dan kelestarian lingkungan adalah aspek yang dipertimbangkan konsumen dalam membeli sayuran organik. Sebagian besar konsumen memperoleh informasi mengenai sayuran organik dari media elektronik. Kualitas produk, terutama kesegaran produk merupakan fokus utama dalam pencarian informasi dan pertimbangan ketika membeli produk. Para konsumen merasa puas dengan produk dan akan tetap membeli sayuran organik di Warung Sehat 1000 Kebun Bandung meskipun, terjadi kenaikan harga. Perkembangan teknologi informasi dan komunikasi, pendapatan, gaya hidup, dan pengetahuan menjadi pertimbangan utama konsumen dalam membeli sayuran organik. Keluarga menjadi referensi utama konsumen dalam pembelian sayuran organik. Sebagian besar pembelian sayuran organik dilakukan konsumen atas dorongan dari diri sendiri.
\end{abstract}

Kata kunci: Sayuran organik, karakteristik konsumen, proses keputusan pembelian

\section{ABSTRACT}

The trend of consumption of organic vegetables in urban areas is increasing. Warung Sehat 1000 Kebun Bandung is one of the organic vegetable marketers in Bandung. The number of competitors and ensuring the availability of organic vegetables according to consumer needs is a problem that is being faced. This study aims to describe consumer characteristics, purchase decision processes, and analyze the factors that influence consumer purchasing decisions. This study applies a quantitative design with a survey technique to 42 respondents. Sampling was done by convenience. Data were analyzed by frequency distribution to determine the description of consumer characteristics, purchasing decision processes, and factors that influence consumer purchasing decisions. Based on the research results, consumers of organic vegetables at Warung Sehat 1000 Kebun Bandung are mostly women aged 36-45 years and 56-65 years, married, are housewives, and have an income of $>R p$. 6,000,000. Consumption of organic vegetables is done erratically. Health and environmental sustainability are aspects that consumers consider in buying organic 
vegetables. Most consumers get information about organic vegetables from electronic media. Product quality, especially product freshness, is the main focus in finding information and considerations when buying products. Consumers are satisfied with the product and will continue to buy organic vegetables at Warung Sehat 1000 Kebun Bandung even though there is an increase in prices. The development of information and communication technology, income, lifestyle, and knowledge are the main considerations for consumers in buying organic vegetables. The family is the main reference for consumers in purchasing organic vegetables. Most of the purchases of organic vegetables are made by consumers at the instigation of themselves.

Keywords: Organic vegetables, consumer characteristics, purchasing decision process

\section{PENDAHULUAN}

Tren konsumsi sayuran organik di perkotaan adalah lebih tinggi dibandingkan di pedesaan, diketahui pada tahun 2016 konsumsi sayuran, baik sayuran organik maupun non-organik di perkotaan mencapai 188 gram per hari, sedangkan tahun sebelumnya hanya mencapai 178 gram per hari. Sebaliknya, tingkat konsumsi sayuran di pedesaan yang mencapai 182 gram per hari pada tahun 2015, menurun menjadi 168 gram per hari pada tahun 2016 (BPS et al., 2017). Konsumsi tersebut menunjukan bahwa pemasaran dan permintaan masyarakat perkotaan terhadap sayuran organik semakin meningkat.

Warung Sehat 1000 Kebun Bandung merupakan salah satu pemasar sayuran organik di Kota Bandung. Produk yang dipasarkan meliputi sayuran dan buah organik, serta produk sehat bebas bahan 5P Pengenyal, Perasa, Pengawet, Pemanis, Pewarna).
Sayuran organik merupakan produk yang banyak diminati oleh para konsumen. Konsumen dapat berbelanja Sayuran organik langsung ke toko fisik atau melakukan pembelanjaan secara online dengan memanfaatkan layanan pengantaran produk dalam kota.

Saat ini banyak kompetitor yang menjual produk serupa. Persoalan lain yang dihadapi Warung Sehat 1000 Kebun adalah menjamin ketersediaan sayuran organik sesuai kebutuhan konsumen. Supaya dapat bersaing, Warung Sehat 1000 Kebun Bandung harus mengenali karakteristik dan kebutuhan konsumen secara utuh. Hal ini ditujukan supaya Warung Sehat 1000 Kebun Bandung mampu mempertahankan eksistensi usaha yang dijalankan, meningkatkan penjualan dan loyalitas konsumen.

Penelitian ini dilakukan untuk memberikan gambaran mengenai karakteristik konsumen, proses keputusan pembelian, dan faktor-faktor yang mempengaruhi keputusan pembelian. 
Studi terdahulu dengan topik serupa sebenarnya sudah banyak dilakukan. Pada studi sebelumnya variabel-variabel yang dipertimbangkan adalah variabel demografis, variabel terkait atribut produk, dan bauran pemasaran pada sayuran organik (Afma Bella Vista, Wiludjeng Roessali, 2021; Ali et al., 2018; Cypert et al., 2019; Devi \& Hartono, 2016; Eny Ratnawati, Endang Siti Rahayu, 2017; Fauzi \& Yuliawati, 2020; Handoko \& Setiawan, 2021; Kesse-Guyot et al., 2013; Kurniasih \& Prihtanti, 2019; Kuswarini Kusno et al., 2017; Novanda, 2020; Rasmikayati et al., 2020; Ratih et al., 2017; Suardika et al., 2014; Utami et al., 2019).

Penelitian yang dilakukan akan memberikan gambaran pada setiap tahapan proses keputusan pembelian yang dilakukan konsumen. Tahapan yang dimaksud adalah pengenalan kebutuhan, pencarian informasi, evaluasi alternatif, keputusan pembelian, dan evaluasi pascapembelian, sehingga karakteristik keputusan pembelian konsumen dapat diketahui (Setiadi, 2019; Sumarwan, 2014).

Berdasarkan penjelasan sebelumnya, dapat dirumuskan beberapa rumusan masalah: 1) bagaimana karakteristik konsumen sayuran organik di Warung Sehat 1000 Kebun Bandung? 2) bagaimana proses keputusan pembelian yang dilakukan konsumen sayuran organik di Warung Sehat 1000 Kebun Bandung? 3) bagaimana deskripsi faktor-faktor yang mempengaruhi keputusan pembelian (budaya, sosial, pribadi, dan psikologis) konsumen sayuran organik di Warung Sehat 1000 Kebun Bandung? Oleh karena itu, tujuan dari penelitian ini adalah: 1) mendeskripsikan karakteristik konsumen sayuran organik di Warung Sehat 1000 Kebun Bandung. 2) mendeskripsikan proses keputusan pembelian yang dilakukan konsumen sayuran organik di Warung Sehat 1000 Kebun Bandung 3) mendeskripsikan faktor-faktor yang mempengaruhi keputusan pembelian (budaya, sosial, pribadi, dan psikologis) konsumen sayuran organik di Warung Sehat 1000 Kebun Bandung.

\section{METODE PENELITIAN}

Penelitian dilakukan di Warung Sehat 1000 Kebun Bandung pada bulan Agustus - Oktober 2021. Objek dalam penelitian ini adalah konsumen sayuran organik. Desain penelitian kuantitatif dengan teknik survei adalah desain yang diterapkan dalam penelitian ini. Tahapan dalam penelitian kuantitatif meliputi 
pengumpulan, analisis, interpretasi, dan penulisan hasil penelitian (Creswell,2016). Sampel yang terdiri atas 42 responden diambil secara convenience, karena sampel diambil seadanya dari populasi (Anderson et al., 2011).

Data primer dalam penelitian diperoleh dari hasil penyebaran kuesioner kepada responden. Data sekunder diperoleh dari buku, jurnal, dan publikasi instansi resmi, seperti Dinas Perkembangan Konsumsi Pangan dan Badan Pusat Statistik.

Data yang telah terkumpul harus diuji validitas dan reliabilitasnya. Pengujian dilakukan menggunakan SPSS. Uji validitas dilakukan untuk menguji ketepatan atau kecermatan sebuah alat ukur. Uji validitas dihitung dengan menggunakan rumus: (Anderson et al., (2011) dalam Kusno et al., 2021).

$$
r_{X Y}=\frac{\mathrm{N} \sum \mathrm{XY}-\sum \mathrm{X} \sum \mathrm{Y}}{\sqrt{\left(N \sum X^{2}-\left(\sum X\right)^{2}\right)\left(N \sum Y^{2}-\left(\sum Y\right)^{2}\right)}}
$$

$\mathrm{r}_{\mathrm{xy}}$ merupakan Koefiesien korelasi antara variabel $\mathrm{X}$ dan $\mathrm{Y}$. N merupakan jumlah responden. $\sum X$ merupakan jumlah skor butir soal. $\sum \mathrm{Y}$ merupakan jumlah skor total butir soal. $\sum X^{2}$ merupakan jumlah skor kuadrat butir soal dan $\sum \mathrm{Y}^{2}$. Jumlah skor total kuadrat butir soal. Nilai $r_{x y}$ dinyatakan valid apabila lebih besar daripada nilai $\mathrm{r}$ tabel product moment pada taraf signifikan 5\%.

Selanjutnya, uji reliabilitas dilakukan untuk mengetahui konsistensi pada instrumen penelitian. Uji validitas dihitung dengan menggunakan rumus: (Anderson et al., 2011).

$$
r_{11}=\left[\frac{k}{k-1}\right]\left[1-\frac{\Sigma s^{2}{ }_{i}}{s^{2}{ }_{t}}\right]
$$

$\mathrm{r}_{11}$ adalah koefisien reliabilitas instrumen. $\mathrm{k}$ adalah jumlah butir pertanyaan yang diuji. $\Sigma s^{2} i$ adalah jumlah varians butir dan $\mathrm{S}^{2} \mathrm{t}$ adalah varians total. Nilai $\mathrm{r}_{11}$ dinyatakan reliabel apabila nilai koefisien Alpha Cronbach adalah lebih dari sama dengan 0,7 (Taber, (2018) dalam Kusno et al., 2021).

Untuk menjawab tujuan penelitian pertama, kedua, dan ketiga dilakukan analisis dengan distribusi frekuensi.

Pengukuran variabel pada konsep proses keputusan pembelian dan faktorfaktor yang mempengaruhi keputusan pembelian (budaya, sosial, pribadi, dan psikologis) dilakukan dengan skala likert 5 kategori dengan indikator sangat tidak setuju (STS), tidak setuju (TS), netral $(\mathrm{N})$, setuju (S), dan sangat setuu (SS).

Variabel pada proses keputusan pembelian terdiri atas frekuensi konsumsi sayuran organik, esensi sayuran organik bagi kesehatan, esensi sayuran organik 
bagi kelestarian lingkungan, sumber informasi, frekuensi mencari informasi, fokus pencarian informasi, spesifikasi kualitas produk yang paling diperhatikan, faktor yang diperhatikan ketika membeli produk, kebiasaan membeli, aspek yang diperhatikan ketika membeli produk, kepuasan produk, dan pengaruh kenaikan harga terhadap keputusan pembelian produk.

Variabel pada faktor-faktor yang mempengaruhi keputusan pembelian konsumen terdiri atas perkembangan teknologi, informasi, dan komunikasi menjadi pertimbangan konsumen dalam membeli sayuran organik, keluarga menjadi referensi dalam membeli sayuran organik, teman menjadi referensi dalam membeli sayuran organik, usia, pekerjaan, pendapatan, gaya hidup, dan pengetahuan menjadi pertimbangan dalam membeli sayuran organik, pembelian sayuran organik dilakukan atas motivasi dalam diri sendiri, dan pembelian sayuran organik dilakukan atas motivasi dari pihak lain (keluarga, teman, tetangga).

\section{HASIL DAN PEMBAHASAN}

\section{Karakteristik Konsumen}

Karakteristik konsumen yang dianalisis terdiri atas usia, jenis kelamin, tingkat pendidikan, pekerjaan, status pernikahan, dan pendapatan. Tabel 1 menunjukkan distribusi frekuensi karakteristik konsumen sayuran organik di Warung Sehat 1000 Kebun Bandung.

Usia konsumen dikelompokkan berdasarkan penggolongan dari Departemen Kesehatan RI (2009) dalam (Amin \& Juniati, 2017). Penggolongan tersebut terdiri atas masa balita (0-5 tahun), masa kanak-kanak (6-11 tahun), masa remaja awal (12-16 tahun), masa remaja akhir (17-25 tahun), masa dewasa awal (26-35 tahun), masa dewasa akhir (36-45 tahun), masa lansia awal (46-55 tahun), masa lansia akhir (56-65 tahun), dan manula ( $>65$ tahun). Konsumen sayuran organik di Warung Sehat 1000 Kebun Bandung sebagian besar berusia 36-45 tahun dan 56-65 tahun (23,8\%). Studi terdahulu menyatakan, usia konsumen sayuran organik didominasi oleh usia 31-40 tahun (Cypert et al., 2019; Fauzi \& Yuliawati, 2020; Rasmikayati et al., 2020; Utami et al., 2019). Terdapat perbedaan antara hasil penelitian yang dilakukan dengan studi terdahulu. Tidak hanya konsumen dewasa saja yang mendominasi konsumsi sayuran organik, tetapi konsumen lansia akhir turut mendominasi konsumsi tersebut. 
Hingga saat ini, konsumen sebagian besar adalah perempuan (Cypert perempuan masih mendominasi dalam et al., 2019; Fauzi \& Yuliawati, 2020; konsumsi sayuran organik $(90,5 \%)$, studi terdahulu menunjukan, bahwa sebagian Handoko \& Setiawan, 2021; Rasmikayati et al., 2020; Ratih et al., 2017; Utami et besar konsumen sayuran organik al., 2019).

Tabel 1. Distribusi Frekuensi Karakteristik Konsumen

\begin{tabular}{cccc}
\hline Karakteristik & Indikator & $\boldsymbol{f}$ & $\mathbf{\%}$ \\
\hline Usia & $12-16$ & 1 & 2,4 \\
& $17-25$ & 5 & 11,9 \\
& $26-35$ & 7 & 16,7 \\
& $36-45$ & 10 & 23,8 \\
& $46-55$ & 9 & 21,4 \\
Jenis Kelamin & $56-65$ & 10 & 23,8 \\
\hline Tingkat Pendidikan & Perempuan & 38 & 90,5 \\
& Laki-laki & 4 & 9,5 \\
\hline Sekerjaan & SD & 0 & 0 \\
& SMP & 1 & 2,4 \\
& SMA & 5 & 11,9 \\
& Diploma & 4 & 9,5 \\
& Sarjana & 20 & 47,6 \\
& Pascasarjana & 12 & 28,6 \\
\hline Pendapatan & Pelajar/mahasiswa & 8 & 19 \\
& Ibus Rumah Tangga & 17 & 40,5 \\
& Pegawai swasta & 6 & 14,3 \\
& PNS & 4 & 9,5 \\
& Wiraswasta & 6 & 14,3
\end{tabular}

Tingkat pendidikan terakhir yang ditempuh konsumen adalah sarjana (47,6\%). Hasil penelitian yang dilakukan adalah sejalan dengan penelitian terdahulu, yakni konsumen sayuran organik berpendidikan tinggi, yaitu sarjana (Cypert et al., 2019; Fauzi \& Yuliawati, 2020; Handoko \& Setiawan,
2021; Rasmikayati et al., 2020; Ratih et al., 2017).

Pekerjaan, sebagian besar konsumen adalah ibu rumah tangga (40,5\%). Hasil tersebut sejalan dengan penelitian yang dilakukan oleh Cypert et al (2019), sebagian besar konsumen sayuran organik adalah ibu rumah tangga. 
Mayoritas konsumen sayuran organik berstatus menikah $(73,8 \%)$. Konsumen yang sudah menikah memiliki tanggungjawab lebih untuk menjaga kesehatan diri sendiri dan anggota keluarga mereka. Penelitian-penelitian terdahulu menunjukan, bahwa konsumen sayuran organik sebagian besar sudah menikah (Cypert et al., 2019; Fauzi \& Yuliawati, 2020).

Pendapatan konsumen dikelompokkan sesuai pengelompokkan yang diberlakukan oleh World Bank. World Bank membagi pendapatan masyarakat ke dalam 3 golongan, yaitu menenag ke bawah $\quad(<\mathrm{Rp} 2.600 .000), \quad$ menengah (Rp2.600.000 - Rp6.000.000), dan menengah ke atas (>Rp6.000.000) World Bank dalam (K. Kusno et al., 2018). Sebagian besar konsumen sayuran organik di Warung Sehat 1000 Kebun Bandung adalah kelas menengah ke atas dengan pendapatan lebih dari Rp6.000.000 (35,7\%). Hal ini mengindikasikan bahwa, semakin tinggi pendapatan seseorang, maka daya beli mereka juga semakin tinggi. Penelitian yang dilakukan oleh
Fauzi \& Yuliawati (2020) dan Ratih et al. (2017) mengemukakan, bahwa pendapatan konsumen sayuran organik adalah >Rp5.000.000. Artinya, pendapatan konsumen sayuran organik saat ini mengalami peningkatan dibandingkan sebelumnya.

\section{Proses Pengambilan Keputusan Pembelian}

\section{Pengenalan Kebutuhan}

Frekuensi konsumsi sayuran organik para konsumen sebagian besar adalah tidak menentu $(57,1 \%)$, karena kebanyakan konsumen hanya melakukan pembelian sayuran organik ketika mereka ingin mengkonsumsi saja. Tabel 2 menunjukan distribusi frekuensi variabel pada tahap pengenalan kebutuhan.

Alasan konsumen mengonsumsi sayuran organik adalah karena esensi bagi kesehatan (69\% Sangat Setuju). Studi terdahulu turut menyatakan pentingnya mengonsumsi sayuran organik bagi kesehatan (Utami et al., 2019). 
Tabel 2. Distribusi Frekuensi Pengenalan Kebutuhan Konsumen

\begin{tabular}{|c|c|c|c|c|}
\hline Dimensi & Variabel & Indikator & $f$ & $\%$ \\
\hline \multirow[t]{14}{*}{ Pengenalan kebutuhan } & \multirow[t]{4}{*}{$\begin{array}{l}\text { Frekuensi mengonsumsi } \\
\text { sayuran organik }\end{array}$} & $\begin{array}{l}1 \text { kali } \\
\text { Seminggu }\end{array}$ & 2 & 4,8 \\
\hline & & $\begin{array}{l}2-3 \text { kali } \\
\text { Seminggu }\end{array}$ & 15 & 35,7 \\
\hline & & $\begin{array}{l}>3 \text { kali } \\
\text { seminggu }\end{array}$ & 1 & 2,4 \\
\hline & & Tidak menentu & 24 & 57,1 \\
\hline & \multirow{5}{*}{$\begin{array}{l}\text { Esesnsi sayuran organik bagi } \\
\text { kesehatan }\end{array}$} & Sangat setuju & 29 & 69 \\
\hline & & Setuju & 12 & 28,6 \\
\hline & & Netral & 1 & 2,4 \\
\hline & & Tidak Setuju & 0 & 0 \\
\hline & & Sangat tidak setuju & 0 & 0 \\
\hline & \multirow{5}{*}{$\begin{array}{l}\text { Esesnsi sayuran organik bagi } \\
\text { kelestarian lingkungan }\end{array}$} & Sangat setuju & 24 & 57,1 \\
\hline & & Setuju & 18 & 42.9 \\
\hline & & Netral & 0 & 0 \\
\hline & & Tidak Setuju & 0 & 0 \\
\hline & & Sangat tidak setuju & 0 & 0 \\
\hline
\end{tabular}

Konsumen yang mengonsumsi sayuran organik karena esensi bagi kelestarian lingkungan menyatakan (57,1\% Sangat Setuju). Konsumen yang memiliki kepedulian yang tinggi terhadap lingkungan disebut konsumen hijau (Irawan \& Vianney B, 2013).

\section{Pencarian Informasi}

Sebagian besar konsumen mengetahui informasi mengenai sayuran organik dari media elektronik, seperti internet, TV, dan radio $(66,7 \%)$. Saat ini internet merupakan sumber pencarian informasi yang paling banyak digunakan konsumen adalah internet. Fokus utama konsumen dalam mencari informasi adalah kualitas produk (42,9\%).

\section{Evaluasi Alternatif}

Spesifikasi kualitas produk yang paling diperhatikan oleh konsumen adalah kesegaran produk (81\%). Ketika membeli sayuran organik, konsumen sangat memperhatikan kualitas pada sayuran organik $(61,9 \%)$. Hasil tersebut sejalan dengan penelitian terdahulu kesegaran produkdan kualitas produk menjadi faktor yang dipertimbangkan konsumen ketika membeli sayuran organik (Afma Bella Vista, Wiludjeng Roessali, 2021; Cypert et al., 2019; Eny Ratnawati, Endang Siti Rahayu, 2017; Fauzi \& Yuliawati, 2020).

\section{Keputusan pembelian}

Kesehatan dan kelestarian lingkungan menjadi aspek utama yang sangat diperhatikan konsumen ketika memutuskan pembelian sayuran organik di Warung Sehat 1000 Kebun Bandung (71,4\%). Tabel 3 menunjukan distribusi frekuensi pada keputusan pembelian 
konsumen ketika membeli sayuran organik.

Pengetahuan konsumen sayuran organik terhadap kelestarian lingkungan adalah tinggi, karena sayuran organik diproduksi untuk meminimalisir dampak negatif terhadap lingkungan (Bargumono, 2016).

\section{Evaluasi Pascapembelian}

Konsumen merasa puas dengan produk sayuran organik di Warung Sehat 1000 Kebun Bandung (47,6\%) konsumen menyatakan sangat puas.

Apabila terjadi kenaikan harga pada sayuran organik (81\%) konsumen akan tetap melakukan pembelian sayuran organik. Angka tersebut mengindikasikan tingginya loyalitas para konsumen.

Tabel 3. Distribusi Frekuensi Keputusan Pembelian Konsumen

\begin{tabular}{|c|c|c|c|c|}
\hline Dimensi & Variabel & Indikator & $f$ & $\%$ \\
\hline \multirow{3}{*}{$\begin{array}{l}\text { Keputusan } \\
\text { pembelian }\end{array}$} & \multirow{3}{*}{$\begin{array}{l}\text { Aspek yang paling } \\
\text { dipertimbangkan } \\
\text { ketika membeli } \\
\text { produk }\end{array}$} & Kesehatan & 12 & 28,6 \\
\hline & & Kelestarian lingkungan & 0 & 0 \\
\hline & & $\begin{array}{l}\text { Keduanya (Kesehatan dan kelestarian } \\
\text { lingkungan) }\end{array}$ & 30 & 71,4 \\
\hline
\end{tabular}

Faktor-faktor yang Mempengaruhi

\section{Keputusan Pembelian}

\section{Budaya}

Budaya masyarakat dapat bersifat abstrak dan berupa objek material, seperti peralatan elektronik, rumah, dan mobil termasuk dalam budaya. Salah satu contoh lain dari budaya adalah teknologi (Sumarwan, 2014).

$$
\text { Perkembangan }
$$

teknologi, informasi, dan komunikasi merupakan variabel yang dianalisis. Distribusi frekuensi faktor budaya ditunjukan oleh Tabel 4.

Tabel 4. Distribusi Frekuensi Faktor Budaya

\begin{tabular}{|c|c|c|c|c|}
\hline Dimensi & Variabel & Indikator & $f$ & $\%$ \\
\hline \multirow[t]{5}{*}{ Budaya } & \multirow{5}{*}{$\begin{array}{l}\text { Perkembangan teknologi } \\
\text { informasi dan komunikasi (TIK) } \\
\text { menjadi pertimbangan pembelian } \\
\text { sayuran organik }\end{array}$} & Sangat setuju & 13 & 31 \\
\hline & & Setuju & 23 & 54.8 \\
\hline & & Netral & 5 & 11,9 \\
\hline & & Tidak Setuju & 1 & 2,4 \\
\hline & & Sangat tidak setuju & 0 & 0 \\
\hline
\end{tabular}

Konsumen sayuran organik di mereka dalam pembelian sayuran Warung Sehat 1000 Kebun Bandung organik. menyatakan $(54,8 \%$ setuju $)$ bahwa perkembangan teknologi, informasi, dan komunikasi menjadi pertimbangan 


\section{Sosial}

Keluarga dan teman merupakan kelompok acuan yang dapat memberi pengaruh informasi terhadap keputusan

Tabel 5. Distribusi Frekuensi Faktor Sosial

\begin{tabular}{|c|c|c|c|c|}
\hline Dimensi & Variabel & Indikator & $f$ & $\%$ \\
\hline \multirow[t]{10}{*}{ Sosial } & \multirow{5}{*}{$\begin{array}{l}\text { Keluarga menjadi referensi } \\
\text { dalam membeli sayuran } \\
\text { organik }\end{array}$} & Sangat setuju & 14 & 33,3 \\
\hline & & Setuju & 19 & 45,2 \\
\hline & & Netral & 8 & 19 \\
\hline & & Tidak Setuju & 1 & 2,4 \\
\hline & & Sangat tidak setuju & 0 & 0 \\
\hline & \multirow{5}{*}{$\begin{array}{l}\text { Teman menjadi referensi } \\
\text { dalam membeli sayuran } \\
\text { organik }\end{array}$} & Sangat setuju & 8 & 19 \\
\hline & & Setuju & 18 & 42,9 \\
\hline & & Netral & 10 & 23,8 \\
\hline & & Tidak Setuju & 5 & 11,9 \\
\hline & & Sangat tidak setuju & 1 & 2,4 \\
\hline
\end{tabular}

Konsumen yang menjadikan Keluarga sebagai referensi dalam membeli sayuran organik (45,2\% setuju). Sedangkan, konsumen yang menjadikan teman sebagai referensi dalam membeli sayuran organik (42,9\% setuju).

Konsumen yang menjadikan keluarga sebagai referensi dalam pembelian sayuran organik adalah lebih banyak dibandingkan menjadikan teman, pembelian konsumen (Sumarwan, 2014). Distribusi frekuensi faktor sosial disajikan pada Tabel 5 .

Tabel 6. Distribusi Frekuensi Faktor Pribadi

\begin{tabular}{|c|c|c|c|c|}
\hline Dimensi & Variabel & Indikator & $f$ & $\%$ \\
\hline \multirow[t]{12}{*}{ Sosial } & \multirow{5}{*}{$\begin{array}{l}\text { Usia menjadi pertimbangan } \\
\text { konsumen dalam membeli } \\
\text { sayuran organik }\end{array}$} & Sangat setuju & 13 & 31 \\
\hline & & Setuju & 16 & 38,1 \\
\hline & & Netral & 7 & 16,7 \\
\hline & & Tidak Setuju & 6 & 14,3 \\
\hline & & Sangat tidak setuju & 0 & 0 \\
\hline & \multirow{5}{*}{$\begin{array}{l}\text { Pekerjaan menjadi } \\
\text { pertimbangan konsumen } \\
\text { dalam membeli sayuran } \\
\text { organik }\end{array}$} & Sangat setuju & 10 & 23,8 \\
\hline & & Setuju & 16 & 38,1 \\
\hline & & Netral & 11 & 26,2 \\
\hline & & Tidak Setuju & 3 & 7,1 \\
\hline & & Sangat tidak setuju & 2 & 4,8 \\
\hline & \multirow{2}{*}{$\begin{array}{l}\text { Pendapatan menjadi } \\
\text { pertimbangan konsumen }\end{array}$} & Sangat setuju & 22 & 52,4 \\
\hline & & Setuju & 13 & 31 \\
\hline
\end{tabular}




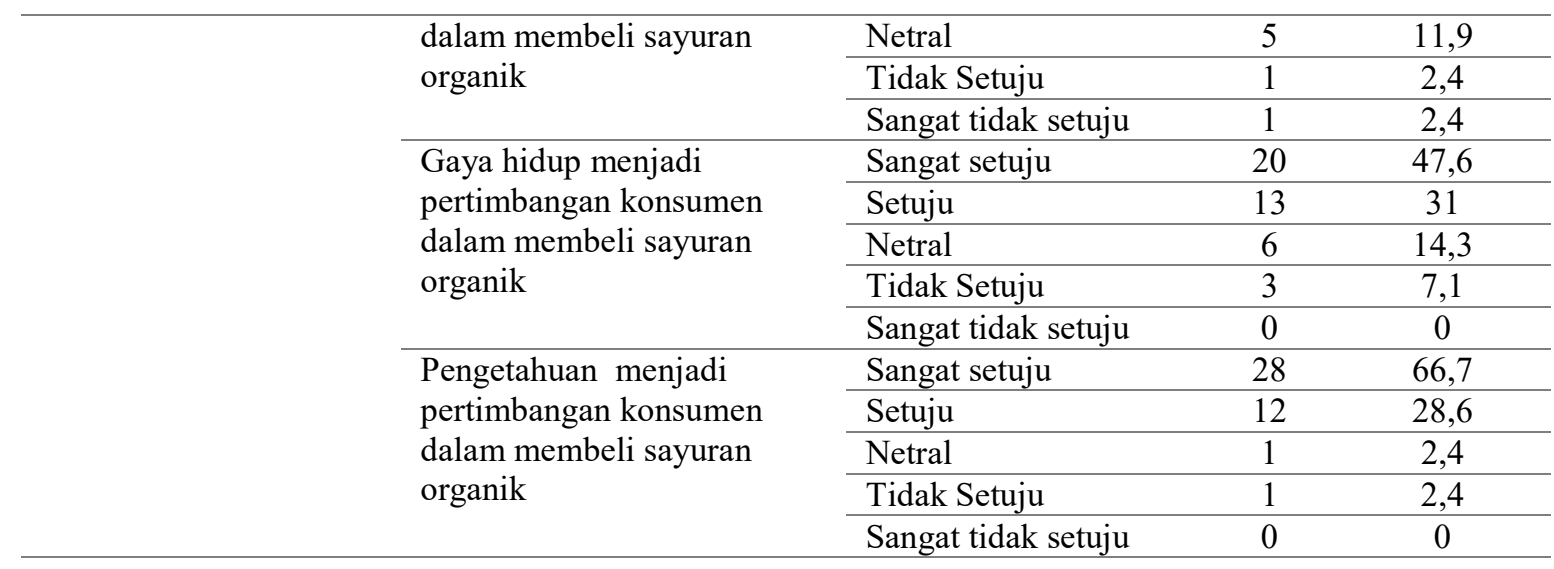

Tabel 6 menunjukan distribusi frekuensi pada faktor pribadi. Konsumen menyatakan setuju pada usia $(38,1 \%)$ dan perkerjaan $(38,1 \%)$ sebagai pertimbangan mereka membeli sayuran organik. Konsumen menyatakan sangat setuju terhadap pendapatan, gaya hidup, dan pengetahuan sebagai pertimbangan dalam keputusan pembelian sayuran organik. Dalam melakukan keputusan pembelian konsumen akan berusaha mencari produk dengan harga yang dapat dijangkau dengan pendapatan yang dimiliki.

\section{Faktor Psikologis}

Motivasi seseorang dapat bersumber dari diri sendiri maupun dari pihak lain. Tabel 7 menunjukan distribusi frekuensi faktor psikologis konsumen pada faktor psikologis.

Konsumen menyatakan sangat setuju bahwa pembelian sayuran organik dilakukan atas dorongan dari diri sendiri (59,5\%). Sedangkan, konsumen menyatakan setuju pada pembelian sayuran organik dilakukan atas dorongan dari pihak lain $(33,3 \%)$. Hal tersebut mengindikasikan kepedulian dan tanggung jawab konsumen yang tinggi terhdap kesehatan dan lingkungan.

Tabel 7. Distribusi Frekuensi Faktor Psikologis

\begin{tabular}{|c|c|c|c|c|}
\hline Dimensi & Variabel & Indikator & $f$ & $\%$ \\
\hline \multirow[t]{10}{*}{ Sosial } & \multirow{5}{*}{$\begin{array}{l}\text { Pembelian sayuran organik } \\
\text { dilakukan atas dorongan dari } \\
\text { diri sendiri }\end{array}$} & Sangat setuju & 25 & 58,5 \\
\hline & & Setuju & 16 & 38,1 \\
\hline & & Netral & 1 & 2,4 \\
\hline & & Tidak Setuju & 0 & 0 \\
\hline & & Sangat tidak setuju & 0 & 0 \\
\hline & \multirow{5}{*}{$\begin{array}{l}\text { Pembelian sayuran organik } \\
\text { dilakukan atas dorongan dari } \\
\text { pihak lain (keluarga, teman, } \\
\text { tetangga) }\end{array}$} & Sangat setuju & 5 & 11,9 \\
\hline & & Setuju & 14 & 33,3 \\
\hline & & Netral & 9 & 21,4 \\
\hline & & Tidak Setuju & 10 & 23,8 \\
\hline & & Sangat tidak setuju & 4 & 9,5 \\
\hline
\end{tabular}




\section{KESIMPULAN DAN SARAN}

\section{Kesimpulan}

Konsumen sayuran organik di Warung Sehat 1000 Kebun Bandung sebagian besar perempuan berusia 36-45 tahun dan 56-65 tahun, sudah menikah, merupakan ibu rumah tangga, dan berpendapatan $>$ Rp6.000.000.

Konsumsi sayuran organik dilakukan secara tidak menentu. Kesehatan dan kelestarian lingkungan adalah aspek yang dipertimbangkan konsumen dalam membeli sayuran organik. Sebagian besar konsumen memperoleh informasi terkait sayuran organik dari media elektronik. Kualitas produk, terutama kesegaran produk merupakan fokus utama dalam pencarian informasi dan ketika membeli produk. Para konsumen merasa puas dengan produk dan akan tetap membeli sayuran organik di Warung Sehat 1000 Kebun Bandung meskipun, terjadi kenaikan harga.

Perkembangan teknologi informasi dan komunikasi, pendapatan, gaya hidup, dan pengetahuan menjadi pertimbangan utama konsumen dalam membeli sayuran organik. Keluarga menjadi referensi utama konsumen dalam pembelian sayuran organik. Sebagian besar pembelian sayuran organik dilakukan konsumen atas dorongan dari diri sendiri.

\section{Saran}

Sehubungan sebagian besar konsumen memperoleh banyak informasi mengenai sayuran organik melalui media elektronik, terutama internet. Warung Sehat 1000 Kebun Bandung sebaiknya mengoptimalkan pemasaran online sayuran organik dan produk lainnya.

\section{DAFTAR PUSTAKA}

Afma Bella Vista, Wiludjeng Roessali, M. M. (2021). Analisis FaktorFaktor Yang Mempengaruhi Keputusan Pembelian Sayuran Organik Di Pasar Modern Kota Semarang Analysis. 5, 108-115. https://jepa.ub.ac.id/index.php/jepa/ article/download/602/297

Ali, T., Alam, A., \& Ali, J. (2018). Factors Affecting Consumers Purchase Behaviour for Health and Wellness Food Products in an Emerging Market. 1-18. https://doi.org/10.1177/0972150918 795368

Amin, M. Al, \& Juniati, D. (2017). Klasifikasi Kelompok Umur Manusia. MATHunesa, 2(6), 34. https://media.neliti.com/media/publ ications/249455-none-

23b6a822.pdf

Bargumono. (2016). Pertanian Organik Solusi Alternatif Pertanian (1st ed.). Global Pustaka Utama Yogyakarta.

BPS, Kementerian Pertanian, BMKG, BNPB, LAPAN, WFP, \& FAO. (2017). Buletin Pemantauan Ketahanan Pangan indonesia Fokus 
Khusus: Tren konsumsi dan produksi buah dan sayur. German Humanitarian Assistance, 8(November), $\quad 1-24$. https://docs.wfp.org/api/documents/ WFP-0000024091/download/

Creswell, J. W. (2016). RESEARCH DESIGN Pendekatan Metode Kualitatif, Kuantitatif, dan Campuran (4th ed.). Pustaka Pelajar.

Cypert, K., Prasetyo, E., \& Setiadi, A. (2019). Analis Is Fak Tor- Fak Tor Yang Mempengaruhi K Eputusan Pembelian Brokoli Organik Di Pasar Modern Gelael Semarang Analysis of Factors Affecting Purchasing Desicion Of Organik Brocolli At Gelael Modern Market In Semarang JSEP Vol 12 No 2 Juli 2019. $12(2)$,

67-79. https://jurnal.unej.ac.id/index.php/J SEP/article/download/10032/7791

Devi, S. R. M., \& Hartono, G. (2016). Faktor-Faktor Yang Mempengaruhi Keputusan Konsumen Dalam Membeli Sayuran Organik. Agric, 27(1), 60. https://doi.org/10.24246/agric.2015. v27.i1.p60-67

Eny Ratnawati, Endang Siti Rahayu, H. I. (2017). Analisis Faktor-Faktor Yang Dipertimbangkan Konsumen Dalam Pembelian Sayuran Organik Di Kota Surakarta. Laboratorium Penelitian Dan Pengembangan FARMAKA TROPIS Fakultas Farmasi Universitas Mualawarman, Samarinda, Kalimantan Timur, 5(Maret), 2535.

https://jurnal.uns.ac.id/agrista/articl e/download/30948/20632

Fauzi, M. I., \& Yuliawati. (2020). Perilaku Konsumen Dalam Membeli Sayuran Organik Po Sayur Organik Merbabu (Studi Kasus Yogyakarta) CONSUMER.
4 ,

752-762.

https://jepa.ub.ac.id/index.php/jep a/article/download/523/267

Handoko, B. I. S., \& Setiawan, I. (2021). Kesediaan Membayar (Willingness To Pay) Konsumen Milenial Dalam Mengkonsumsi Sayuran Organik (Suatu Kasus pada Warung Sehat 1000 Kebun, Kota Bandung). Mimbar Agribisnis: Jurnal Pemikiran Masyarakat Ilmiah Berwawasan Agribisnis, 7(1), 911. https://doi.org/10.25157/ma.v7i1.48 73

Irawan, A., \& Vianney B, A. (2013). Pengaruh Green Practice Terhadap Green Consumer Behavior Di The Kemangi Restaurant, Hotel Santika Pandegiling Surabaya. Journal of Chemical Information and Modeling, 53(9), 1689-1699. http://publication.petra.ac.id/index. php/manajemenperhotelan/article/download/3482/3 152

Kesse-Guyot, E., Péneau, S., Méjean, C., Szabo de Edelenyi, F., Galan, P., Hercberg, S., \& Lairon, D. (2013). Profiles of Organic Food Consumers in a Large Sample of French Adults: Results from the Nutrinet-Santé Cohort Study. PLoS $O N E$, $8(10)$. https://doi.org/10.1371/journal.pon e.0076998

Kurniasih, P., \& Prihtanti, T. M. (2019). Faktor - Faktor Yang Mempengaruhi Keputusan Konsumen Dalam Pembelian Sayuran Organik Di Kota Salatiga (Factors That Influence Costumer Dicisions In Purchasing Organic Vegetables In Salatiga) Putri Kurniasih, Tinjung Mary Prihtanti. 44, 347-356. https://ojs.uniskabjm.ac.id/index.php/ziraah/article/v iewFile/2106/1798 
Kusno, K., Imannurdin, A., Syamsiyah, N., \& Djuwendah, E. (2018). Analysis of rice purchase decision on rice consumer in Bandung city. IOP Conference Series: Earth and Environmental Science, 142(1). https://doi.org/10.1088/17551315/142/1/012039

Kusno, Kuswarini, Fauziah, K. R., Rochdiani, D., \& Heryanto, M. A. (2017). Keputusan Konsumen di Kota Bandung Memilih Pasar Kecil Kaitannya dengan Penyediaan Sayuran Organik yang Dipengaruhi oleh Iklim. Prosiding Seminar Nasional Mitigasi Dan Strategi Adaptasi Dampak Perubahan Iklim Di Indonesia, 70-80. http://registrasi.seminar.uir.ac.id/pr osiding/sem_nas17/file/SCI01710_ Kuswarini\%20Kusno.pdf

Kusno, Kuswarini, Liandy, R. S., Mukti, G. W., \& Sadeli, A. H. (2021). Driven factors for purchasing decision and satisfaction of organic rice consumers on supermarket - A study in Indonesia. Journal of Agricultural Sciences - Sri Lanka, 16(2), 271-282. https://doi.org/10.4038/jas.v16i2.93 33

Novanda, R. R. (2020). Faktor-Faktor Yang Berpengaruh Terhadap Keputusan Pembelian Sayuran Organik Di Kota Bengkulu. Jurnal Agribest, $\quad 4(2), \quad 94-100$. https://doi.org/10.32528/agribest.v4 i2.3549

Rasmikayati, E., Shafira, N. A., Fauziah, Y. D., Ishmah, H. A. N., Saefudin, B. R., \& Utami, K. (2020). Keterkaitan antara Karakteristik Konsumen dengan Tingkat Kepuasan Mereka dalam Melakukan Pembelian Sayuran Organik. Agricore: JurnalAgribisnis Dan Sosial Ekonomi Pertanian Unpad, 5(1),
104-114.

https://doi.org/10.24198/agricore.v 5i1.28853

Ratih, N. N. M., Susilowati, D., \& Hindarti, S. (2017). Analisis Faktor-Faktor Preferensi Konsumen Yang Mempengaruhi Keputusan Pembelian Sayuran Organik (Studi Kasus: Pelanggan Super Indo Semarang). Jurnal Ilmu Administrasi Bisnis, 6(4), 21-30. http://riset.unisma.ac.id/index.php/ SEAGRI/article/view/4590/4139

Setiadi, N. J. (2019). Perilaku Konsumen Perspektif Kontemporer pada Motif, Tujuan, dan keinginan Konsumen (3rd ed.). Prenadamedia Group.

Suardika, M. P., Ambarawati, G. A. A., \& Sukaatmadja, P. (2014). Analisis perilaku konsumen terhadap keputusan pembelian sayur organik cv golden leaf farm bali. Jurnal Manajemen Agribisnis, 2(1), 1-10. https://ojs.unud.ac.id/index.php/agri bisnis/article/download/9942/7419

Sumarwan, U. (2014). Perilaku Konsumen (R. Sikumbang (ed.); 2nd ed.). Penerbit Ghalia Indonesia. Utami, K., Rauf, A., \& Salmiah. (2019). Analisis Perilaku Konsumen dalam Pengambilan Keputusan Pembelian Sayur Organik di Kota Medan Consumer Behavior Analysis in Organic Vegetables Decision Making in Medan City. Jurnal Agroteknologi Dan Ilmu Pertanian, 3(2), 75-86.

https://www.researchgate.net/publication/ 333777722_Analisis_Perilaku_Kon sumen_dalam_Pengambilan_Keput usan_Pembelian_Sayur_Organik_di _Kota_Medan 